\title{
The ammonium lactate soluble potassium and phosphorus content of the soils of north-east Hungary region: a quantifying study
}

\author{
Anita Jakab',2* \\ 1National Agricultural Research and Innovation Centre, Újfehértó, Hungary \\ ${ }^{2}$ University of Debrecen, Debrecen, Hungary \\ *Correspondence: Dr. Anita Jakab, email: jakab.anita@fruitresearch.naik.hu, address: National Agricultural Research \\ and Innovation Centre, Vadas tag 2. Újfehértó, 4244 Hungary, Office Tel. number: +3642590007
}

Received: 10/11/2019

Accepted (Online first): 21/01/2020

Vol./Issue/Year: 1(1), 2020

Competing interests: Author(s) stated no compete of interest.

Edited by Lowy A. Daniel

Grant information: The author(s) declared that no grants were involved in supporting this work.

Copyright 2020 (C) The Author(s). This is an Open Access article under the CC-BY 4.0 license published by Dama Research Center limited a private company limited by shares organized and existing under the laws of Hong Kong, with its head office located at Room 409, Beverley Commercial Centre, 87-105 Chatham Road South, Tsim Sha Tsui, Kowloon- Hong Kong and company number: 2875213.

How to cite: Jakab, A. "The ammonium lactate soluble potassium and phosphorus content of the soils of north-east Hungary region: a quantifying study" DRC Sustainable Future 2020, 1(1), 7-13 DOI: 10.37281/DRCSF/1.1.2

\section{ABSTRACT:}

Half of the orchards of Hungary are in Szatmár-Bereg County. The county is in North-east Hungary. The total area of this micro region $\left(5936 \mathrm{~km}^{2}\right)$ covers $6.6 \%$ of the country's overall territory $\left(90030 \mathrm{~km}^{2}\right)$. The most common soil types of the planted areas in Szatmár and Bereg region are acidic meadow (WRB Vertisol) and acidic sediment (WRB Fluvisol) soils, while sandy (WRB Arenosol) soils dominate the neighboring area (Nyírség). In this study several chemical parameters were investigated, including ammonium lactate $(\mathrm{AL})$ soluble phosphorus and potassium content of soils of fruit plantations. Ammonium soluble phosphorus and potassium contents of soils are represent determining the current amount of phosphorus and potassium available to plants in the soil solution. We established nutrient deficiency caused by acidification of soils examined. Results of soil analysis can contribute to sustainable soil and land use by considering soil and plant nutrient requirements.

Keywords: AL- $\mathrm{P}_{2} \mathrm{O}_{5}, \mathrm{AL}-\mathrm{K}_{2} \mathrm{O}$, Northeastern Hungary

\section{Introduction}

Diversity of Hungarian soils has been shaped by the rocks of the Carpathian Basin, climatic conditions, configuration of the terrain, biological factors, consequences of human activity, and effects of time (Michéli, 2016.)

Soil is a renewable natural resource with finite renewable ability. The connective and intermediary functions of soils are not negligible. Anthropogenic effects have deteriorated the multifunctional nature and quality of soils, causing a need to protect the multifaceted functions of soils. These principles represent part of the foundations of sustainable development (KVVM, 2017). Inland excess water (IEW) is a form of surplus surface water, frequently regarded as a specific flood type. It occurs most often in local depressions of large flat areas, irrespective of river floods and the surface water networks. Pasztor and co-workers investigated parameters that quantize the effects of soil geology, groundwater, land use, and hydrometeorology on the formulation of 


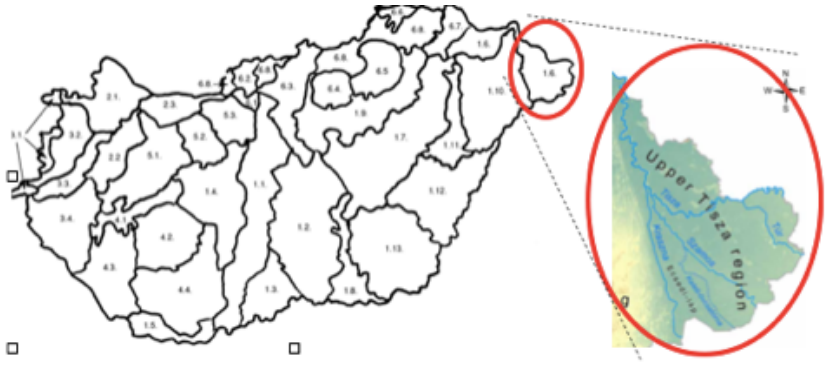

Figure 1. Map of sampling area: Szatmár and Bereg Counties in North-east Hungary (circled on the country's map, Left side - source: Stefanovits, P.; Filep, Gy.; Füleky, Gy. Talajtan (Soil Science); Zoomed in image of the area approximately equivalent to the Upper Tisza Region, Right side - adapted from: Pasztor et al., 2015. (Szatmár and Bereg Counties in North-east Hungary). GPS coordinated (WGS) of 50 soil samples are available as supporting material. Figshare: Dama Research Center limited (2020): GPS coordinated (WGS) of 50 soil samples. figshare. Dataset. https://doi.org/10.6084/m9.figshare.11749824.v2

inland excess water. Legacy maps displaying IEW events were used as a reference dataset, regression kriging interpolation was applied for determining spatial inference with the correlation between environmental factors and flooding by using multiple linear regressions. A stochastic factor was generated and added to the regression results, producing the final flooding hazard map, which may be a useful asset to numerous land-related activities (Pasztor et al., 2015.) The established methodology was applied to the study of IEW in the Great Hungarian Plain (GHP), where it can cause major land degradation in the agricultural areas. An innovative method for mapping the probability of IEW flooding was proposed, a procedure based on the geostatistical modelling of the relationship between natural and human driving factors and the occurrence of IEW inundations. Results revealed that a significant part of the GHP (about 500,000 hectares) is moderately or highly affected by IEW flooding, caused by the combination of multiple factors that act simultaneously. IEW inundation probability maps were drawn, which can meet future challenges in agricultural management and the adaptations to climate change effects (Bozan et al., 2018.)

From 1965 to 1995, one can distinguish different periods of fertilizer use in Hungarian agriculture. Minimal usage of chemical fertilizers was typical prior to year 1960, with NPK fertilizer doses less than an average of $30 \mathrm{~kg}$ per hectare. From 1960 to 1975, high doses of NPK fertilizers, $275 \mathrm{~kg}$ per hectare, were applied. After 1975, a stagnant and then rapidly decreasing usage of fertilizers became typical to Hungarian agriculture, until 1990. Starting 1990 to present, one-sided nitrogen fertilization and the evisceration of soils has been dominant. A decreasing number of macronutrients resulted in waning average yield, along with the degrading of production quality and safety (Loch, 2015). The number and area of intensive orchards in Hungary and in Szabolcs-SzatmarBereg County are becoming more frequent over the last decades of 2000 (Pető et al., 2014). One major condition for plantations is the suitability of soil in the agricultural area selected for planting (Kállay, 2014).

The goal of this work is to screen and evaluate some chemical parameters of soils, typical for orchards in Szatmár and Bereg regions in North-east Hungary. Attention is paid to the quantitation of ammonium soluble phosphorus and potassium content. By considering soil and plant nutrient requirements, obtained results are expected to contribute to sustainable soil and land use.

\section{Methods}

Discussed in this section are the analytical procedures, performed according to Hungarian national standards and recommendations made by FAO. Soil rating was done based on macronutrient content of soil samples, as recommended by the scientific literature. All measurements were performed at the Soil and Plant Testing Laboratory of Magyar Kertészeti Szaporítóanyag Nonprofit Ltd. (Hungarian Horticultural Sweeper Nonprofit Ltd.) in Újfehértó (a city located $16 \mathrm{~km}$ away from Nyíregyháza) in Szabolcs-Szatmár-Bereg County, Hungary.

\subsection{Soil sampling}

In this study, the nutrient content of soils investigated in areas selected for planting orchards, over a time span from 2015 to 2016. Szabolcs-Szatmar-Bereg County is at the north-eastern end of Hungary (see area circled with red in Figure 1), having borders with Ukraine, Slovakia, and Romania. Its total land area is $5936 \mathrm{~km} 2$. Tisza River and its tributaries cross the county. The Upper Tisza region is an alluvial plain, where Holocene clay and silt sediments had been deposited on Pleistocene gravel. The alluvial fan of the Nyírség was formed by rivers in the Pleistocene, being covered by sand (and partly by loess) in the Würm glacial period. In present, the dominant landscape elements of the Upper Tisza region are fixed and semi-fixed sand forms, dunes, deflation depressions, and erosion-deflation lakes. Alluvial and meadow soils are also found there (Pásztor et al., 2015). 25-25 locations were selected randomly from Szatmár and Bereg Regions (Figure 1.), which were representative to the actual conditions of the soils. One should emphasize that the selected locations were not suitable for being compared to one another, because of diverse soil parameters, specific to each site. Our assessments followed the steps below:

- Classification of soil points based on the selected field points, consistent with the soil protection and nutrient management plans of orchards, corresponding to MÉM NAK (Mérei, Zs., Ed., 1979). Considered soil categories were the followings: 
I. chernozem or steppe soils,

II. brown forest soil,

III. meadow and gleyic brown forest soils,

IV. sandy and loose soils, and

V. solonchak or solonetz soils.

AL-soluble phosphorus and potassium content of soils were determined according to Egnér and co-workers (1960) and Hungarian standard MSZ 20135 (MSZ 20135:1999).

- Subsequent to soil type determination, the macronutrient content of soil samples was examined (Mérei, Zs., Ed., 1979). The groups of ammonium lactate soluble phosphorus and potassium content of soils were the followings: very low, low, medium, good, or very good, as listed in Tables 2 and 3.

- As the final step, soil sample analysis was quantified and evaluated for serving as guideline to agricultural experts and farmers.

\subsection{Sample preparation}

Soil samples were air-dried. Fine earth fraction was separated by sieving the dry sample with a $2 \mathrm{~mm}$ sieve. Clods, gravel, rock fragments, etc. not passing through the sieve were treated separately. When air-drying caused irreversible changes in the properties of certain soil samples (e.g. in peat and soils with andic properties), samples are kept and treated in the fieldmoist state (WRB, 2015).

\subsection{AL-soluble phosphorus $\left(\mathrm{P}_{2} \mathrm{O}_{5}\right)$ content}

AL-soluble phosphorus $\left(\mathrm{P}_{2} \mathrm{O}_{5}\right)$ content of soils was determined by UV/VIS spectrophotometry according to Egnér and co-workers (1960), Hungarian standard MSZ 20135 on Soil analysis, the determination of the soluble nutrients content of the soil (MSZ 20135:1999), and the analytical procedures recommended by FAO (WRB, 2015). A Model Lambda 25 UV/VIS Perkin spectrophotometer was used.

\subsection{Potassium $\left(\mathrm{K}_{2} \mathrm{O}\right)$ content}

Potassium $\left(\mathrm{K}_{2} \mathrm{O}\right)$ content was assessed by atomic absorption spectrophotometry, according to the methodology specified above, with a Model PinAAcleTM 900H instrument (Perkin Elmer). This high-performance atomic absorption spectrometer is a combined flame/furnace system with continuum source background correction. All instrumental analyses were carried out at least in triplicate.

\section{5. pH-KCl measurements}

$\mathrm{pH}-\mathrm{KCl}$ measurements were carried out with a Model innoLab® $\mathrm{pH} 7310 \mathrm{P}$ benchtop digital $\mathrm{pH}$-meter, according to the Hungarian standard for soil analysis (MSZ-080206-2, 1978).

\subsection{Carbonate content}

To determine calcium carbonate content, we measured the volume of released $\mathrm{CO}_{2}$ in the reaction of $10 \%$ hydrochloric acid and air-dried soil samples using Scheibler calcimeter according to MSZ-08-0206-2, 1978. Results are referred to as calcium carbonate equivalent (see Table 2).

\subsection{Bound index according to Arany $\left(K_{A}\right)$}

Bound index $\mathrm{K}_{\mathrm{A}}$ was determined by a manual method, according to the procedure prescribed by the pertaining Hungarian standard (MSZ-08-0205, 1978). Defined by Equation 1, bound index $\mathrm{K}_{\mathrm{A}}$ represents the quantity of water contained by $100 \mathrm{~g}$ of air-dried soil, at the interface between plasticity and free-flow liquidity. This parameter can be used for characterizing the the physical nature and texture of soils.

$$
K_{A}=100 * V / m
$$

where: $\mathrm{V}$ is volume of frozen water $(\mathrm{mL})$ $\mathrm{m}$ is mass of weighed sample $(\mathrm{g})$

Based on the value of Bound index $\mathrm{K}_{\mathrm{A}}$ the following soil texture groups can be identified:

Table 1. Soil texture groups according to $K_{A}$

\begin{tabular}{lc}
\hline \multicolumn{1}{c}{ Soil texture group } & $\mathbf{K}_{\mathbf{A}}$ \\
\hline Coarse sand & $<25$ \\
Sand & $25-30$ \\
Sandy loam & $31-37$ \\
Loam & $38-42$ \\
Clay loam & $43-50$ \\
Clay & $51-60$ \\
Heavy material & $>60$ \\
\hline
\end{tabular}

Bound index KA values listed in Table 3 are in the range from less than 30 to over 50 , but in most cases in a narrower range from 38 to 42 , which designate loam type soils.

\subsection{Soil rating}

Subsequent to soil type determination, the macronutrient content of soil samples was examined according to Zsolt Mérei (Mérei, Zs., Ed., 1979). Based on the ammonium lactate-soluble phosphorus and potassium content the soils were rated as: very low nutrient content, low content, medium content, good soils, or very good soil. Soil category assignments are listed in Tables 1 and 2 .

As the final step, soil sample analysis was quantified and evaluated for serving as guideline to agricultural experts and farmers. Whenever the soil of the investigated area does not reach the medium level regarding the given nutrient, supplementing that nutrient shall be prescribed.

\section{Results and Discussion}

Overall, most investigated areas had an acidic $\mathrm{pH}$, which leads to the deterioration of nutrient uptake. In terms of bonding, most are bonded above 45 , which refers to clay loam, clay, and heavy clay. Samples either do not con- 
Table 2. Ammonium lactate-soluble phosphorus content of soil types, which determines the available phosphorus content of soil, according to the rating criteria proposed by Zs. Mérei (Mérei, Zs., Ed., 1979).

\begin{tabular}{|c|c|c|c|c|c|c|}
\hline \multirow{2}{*}{$\begin{array}{l}\text { Soil categories of the } \\
\text { agricultural production sites }\end{array}$} & \multirow{2}{*}{$\begin{array}{l}\text { Carbonate content } \\
\text { of soil }\left(\% \mathrm{CaCO}_{3}\right)\end{array}$} & \multicolumn{5}{|c|}{$\mathrm{AL}-\mathrm{P}_{2} \mathrm{O}_{5}(\mathrm{ppm})$} \\
\hline & & $\begin{array}{l}\text { very } \\
\text { low }\end{array}$ & low & $\begin{array}{l}\text { medi } \\
\text { um }\end{array}$ & good & very good \\
\hline I. chernozem soils & $\begin{array}{l}>1 \\
<1\end{array}$ & $\begin{array}{l}<50 \\
<40\end{array}$ & $\begin{array}{l}61-90 \\
41-60\end{array}$ & $\begin{array}{l}91-150 \\
81-130\end{array}$ & $\begin{array}{l}151-250 \\
131-200\end{array}$ & $\begin{array}{l}251-400 \\
201-401\end{array}$ \\
\hline II. brown forest soils & $\begin{array}{l}>1 \\
<1\end{array}$ & $\begin{array}{l}<40 \\
<30\end{array}$ & $\begin{array}{l}41-70 \\
31-60\end{array}$ & $\begin{array}{l}71-120 \\
61-100\end{array}$ & $\begin{array}{l}121-200 \\
101-160\end{array}$ & $\begin{array}{l}201-400 \\
161-360\end{array}$ \\
\hline III. meadow/gleyic soils & $\begin{array}{l}>1 \\
<1\end{array}$ & $\begin{array}{l}<40 \\
<30\end{array}$ & $\begin{array}{l}41-70 \\
31-60\end{array}$ & $\begin{array}{l}71-110 \\
61-100\end{array}$ & $\begin{array}{l}111-180 \\
101-150\end{array}$ & $\begin{array}{l}181-380 \\
151-350\end{array}$ \\
\hline IV. sandy and loose soils & $\begin{array}{l}>1 \\
<1\end{array}$ & $\begin{array}{l}<50 \\
<30\end{array}$ & $\begin{array}{l}51-80 \\
31-60\end{array}$ & $\begin{array}{l}81-130 \\
61-100\end{array}$ & $\begin{array}{l}131-250 \\
101-200\end{array}$ & $\begin{array}{l}251-450 \\
201-400\end{array}$ \\
\hline V. solonetz or solonchak soils & $\begin{array}{l}>1 \\
<1\end{array}$ & $\begin{array}{l}<50 \\
<30\end{array}$ & $\begin{array}{l}51-80 \\
31-60\end{array}$ & $\begin{array}{l}81-130 \\
61-100\end{array}$ & $\begin{array}{l}131-200 \\
101-150\end{array}$ & $\begin{array}{l}201-400 \\
151-350\end{array}$ \\
\hline
\end{tabular}

tain carbonate, or they contain exclusively carbonate. Based on the methodology described in detail in Section 2 , we obtained for various soil samples carbonate (Ca$\left.\mathrm{CO}_{3}\right)$ and lactate-soluble phosphorus $\left(\mathrm{P}_{2} \mathrm{O}_{5}\right)$ contents listed in Table 2, where soil ratings are also disclosed.

Soil categories of agricultural production sites according to their ammonium lactate soluble potassium content are provided in Table 3. Data listed in Tables 2 and 3 represent own research results.

Selected soil sampling points in Szatmár and Bereg regions were categorized as meadow (III) and sandy soils (IV). In addition, solonetz/solonchak soils (V) were found. Most of the tested soils were slightly acidic, with $\mathrm{pH}<7$. One intends to secure a medium nutrient level for all soil types. Analyzed ranges of AL-soluble phos- phorus and potassium contained by the soil samples are shown in Figures 2 and 3. Obtained results are displayed in columns and labeled by the soil type (III, IV, and V). The soluble nutrient content refers to the upper $60 \mathrm{~cm}$ layer of the soil.

In Szatmár region, over $63 \%$ of III soils contained low or very low AL-soluble phosphorus (Figure 2). In this region, all soils belonging to soil $\mathrm{V}$ category containes very low soluble nutrients. Similar results were observed in the Bereg Plain. For III soil category, the percentage of poorly supplied areas was $57 \%$. In the meanwhile, $100 \%$ of soils IV had low/very low nutrient content. When the orchard soils provide moderate phosphorus supply (medium or lower nutrient content), use of addi-

Table 3. Ammonium lactate-soluble phosphorus content of soil types, which determines the available phosphorus content of soil, according to the rating criteria proposed by Zs. Mérei (Mérei, Zs., Ed., 1979).

$\mathrm{AL}-\mathrm{P}_{2} \mathrm{O}_{5}$ (ppm)

Soil categories of the agricultural production sites
Soil plasticity index according to Arany (KA)

$\begin{array}{lll}\text { very low medium good } & \text { very } \\ \text { low good }\end{array}$

\begin{tabular}{|c|c|c|c|c|c|c|}
\hline I. chernozem soils & $\begin{array}{l}>42 \\
<42\end{array}$ & $\begin{array}{r}<100 \\
<80\end{array}$ & $\begin{array}{l}101-160 \\
81-130\end{array}$ & $\begin{array}{l}161-240 \\
131-200\end{array}$ & $\begin{array}{l}241-360 \\
201-300\end{array}$ & $\begin{array}{l}351-550 \\
301-500\end{array}$ \\
\hline II. brown forest soils & $\begin{array}{l}>38 \\
<38\end{array}$ & $\begin{array}{l}<90 \\
<60\end{array}$ & $\begin{array}{l}91-140 \\
61-100\end{array}$ & $\begin{array}{l}141-210 \\
101-160\end{array}$ & $\begin{array}{l}211-300 \\
161-250\end{array}$ & $\begin{array}{l}301-500 \\
251-450\end{array}$ \\
\hline III. meadow/gleyic soils & $\begin{array}{l}>50 \\
<50\end{array}$ & $\begin{array}{r}<150 \\
120\end{array}$ & $\begin{array}{l}151-250 \\
121-200\end{array}$ & $\begin{array}{l}251-380 \\
201-330\end{array}$ & $\begin{array}{l}381-500 \\
331-450\end{array}$ & $\begin{array}{l}501-700 \\
451-650\end{array}$ \\
\hline IV. sandy and loose soils & $\begin{array}{c}>30-38 \\
<30\end{array}$ & $\begin{array}{l}<90 \\
<50\end{array}$ & $\begin{array}{c}91-120 \\
51-80\end{array}$ & $\begin{array}{c}121-160 \\
81-120\end{array}$ & $\begin{array}{l}161-220 \\
121-180\end{array}$ & $\begin{array}{l}221-420 \\
181-380\end{array}$ \\
\hline V. solonetz or solonchak soils & $\begin{array}{l}>42 \\
<42\end{array}$ & $\begin{array}{r}<120 \\
<80\end{array}$ & $\begin{array}{l}121-160 \\
81-120\end{array}$ & $\begin{array}{l}161-220 \\
121-180\end{array}$ & $\begin{array}{l}221-300 \\
181-250\end{array}$ & $\begin{array}{l}301-500 \\
251-450\end{array}$ \\
\hline
\end{tabular}




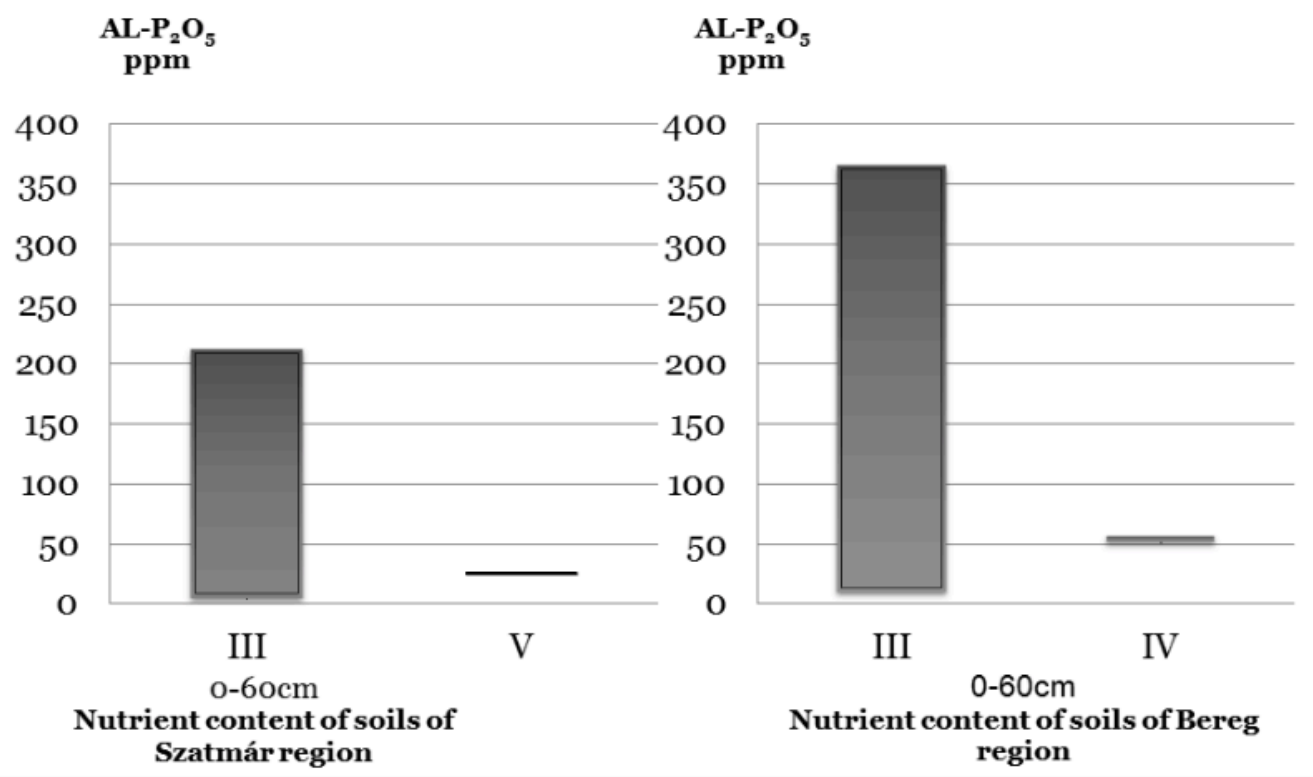

Figure 2. AL-soluble phosphorus content of soil samples in Szatmár and Bereg regions

tional nutrients is necessary. In Szatmár region, a variable amount of phosphorus, in the range of 2-96 ppm, is required for attaining an adequate medium $100 \mathrm{ppm}$ phosphorus resource. In Bereg region, 6-90 ppm of phosphorus are required to meet the prescribed $100 \mathrm{ppm}$ (medium level), while 24-29 ppm of phosphorus are needed to meet the stated 80 ppm supply.

In Szatmár region over $54 \%$ of the III soil category contained low or very low AL-soluble potassium. In this region, $100 \%$ of the $\mathrm{V}$ soils had favorable potassium content (Figure 3).

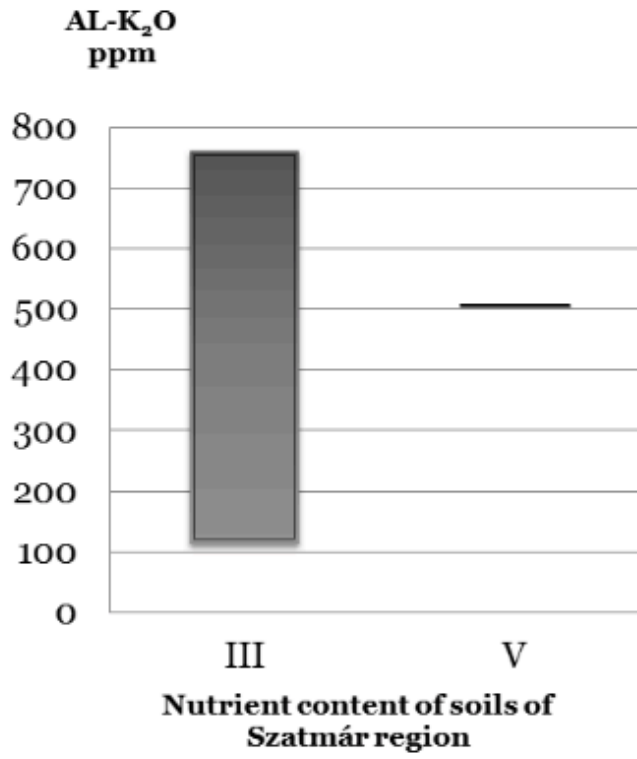

\section{AL- $\mathrm{K}_{2} \mathbf{O}$ ppm}

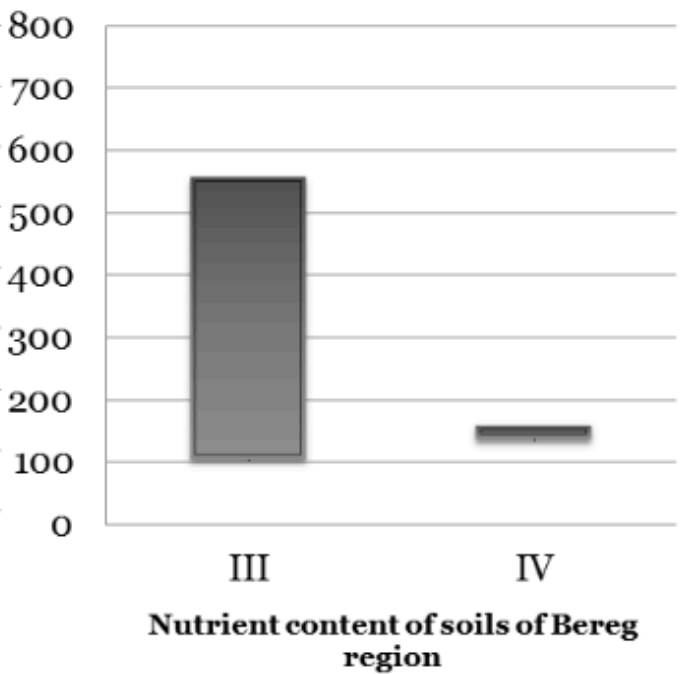

Figure 3. AL-soluble potassium content of soil samples in Szatmár and Bereg regions

In the Bereg Plain, $57 \%$ of samples that belong to III soil category provide low/very low potassium supply. In the meantime, IV soil category samples provided good or very good potassium supply, so that these soils did not require any fertilization. For orchard soils with moderate or lower potassium content, further nutrient supply was required. In Szatmár region, 23-136 ppm of potassium were necessary to reach a suitable 180-250 ppm potassium supply. In Bereg region, 13-147 ppm of phosphorus were needed to meet the prescribed $250 \mathrm{ppm} P$ level, 
and 3-14 ppm of potassium is necessary to achieve the imposed 160 ppm K supply.

\section{Conclusions}

Fifty randomly selected zones from Szatmár and Bereg Counties revealed in a representative manner the actual condition of soils in these areas. On the other hand, $\mathrm{re}^{-}$ sults obtained in these locations were not suitable for being compared to one another, given diverse soil parameters, specific to each sampling site. Most of the analyzed soils contained low nutrient supply and had slightly acidic pH. The Hungarian Soil Protecting Information and Monitoring (Várallyay et al., 2008) database provides information on the nutrient supply and $\mathrm{pH}$ of soils of Hungary, particularly in Szatmár and Bereg Counties. Therefore, this database is suitable for comparison. According to the SIM database, phosphorus supply of soils are the followings: $42 \%$ of soils contain below 100 ppm P, 26\% have 100-200 ppm P content, $21 \%$ of soils fall in the phosphorus range between 200-400 ppm, and only a small percentage of soils are abundant in phosphorus (above $400 \mathrm{ppm}$ ). In this research, over $60 \%$ of the studied plantations soils had low or very low phosphorus resources. Moderate acidity of soil solution $(\mathrm{pH}<5,5)$ affects the amount of soluble phosphorus content. Similar conclusions were drawn by Juhos et al. (2019) on acidic soils and Tóth et al 2011; 2013 on acidifying soils in the absence of organic matter in Hungary. A considerable proportion of soils in Szabolcs-Szatmár-Bereg Counties are acidic; for these soils phosphorus nutrient replenishment is very important, a conclusion supported by our results.

More than $50 \%$ of orchard soils had medium or greater potassium content, like the potassium supply reported in the SIM database.

It is essential to renewal the domestic soil system for needed supplies of nutrients. In present, Hungarian soils are comparable to those in other countries with soil classification and soil nutrition management improvements (Michéli et al., 2015; Sisák, 2016).

Soil analyses reported in this paper enable a better understand of soil and plant nutrient requirements for sustainable soil and land use. Under favorable soil conditions, it becomes easier to create an optimal nutrient supply for orchards. By applying soil protection and nutrient management plans one can secure the balance between soil and plant systems in Hungary.

In addition, the reported methodology is of generic use, and can be applied directly or in modified versions to any types of soils in different countries. Owing to the straightforward and cost-effective analytical methods reported in this paper, we are confident that our contribution may serve agricultural improvement projects in developing countries, as well.

\section{Data availability}

\section{Supporting material}

WGS GPS coordinates of 50 sampling points:

Figshare: Dama Research Center limited (2020): GPS coordinated (WGS) of 50 soil samples. figshare. Dataset. https://doi.org/10.6084/m9.figshare.11749824.v2

Figshare: Dama Research Center limited (2020): Detailed results obtained in the analysis of 50 selected soil samples .xlsx. figshare. Dataset. https://doi.org/10.6084/ m9.figshare.11717862.v1

\section{References}

Bozan, C.; Takacs, K.; Korosparti, J.; Laborczi, A.; Turi, N.; Pasztor, L. "Integrated spatial assessment of inland excess water hazard on the Great Hungarian Plain." Land Degradation \& Development. 2018, 29(12): 43734386. DOI: $10.1002 / 1 \mathrm{dr} .3187$

Egnér, H.; Riehm, H.; Domingo, W.R. "Untersuchungen über die chemische Bodenanalyse als Grundlage für die Beurteilung des Nährstoffzustandes der Böden (Investigations of the chemical soil analysis as a basis for the assessment of the nutrient status of the soils)". II. K. LantbrHögsk. Ann 1960. 26: 199-215.

Juhos, K ; Czigány, Sz ; Madarász, B ; Ladányi, M. "Interpretation of soil quality indicators for land suitability assessment - a multivariate approach for Central $\mathrm{Eu}^{-}$ ropean arable soils." Ecological Indicators 2019, 99: 261-272.

Kállay T-né (2014): Gyümölcsösök termőhelye (Habitat for orchards). Mezőgazda Kiadó, Budapest. pp. 1-236.

Loch, J.: "Nutrient management in Hungary - A review." Agrokémia és Talajtan, Akadémia Kiadó 2015, Budapest, pp. 373-382.

Mérei, Zs., Ed. "Állókultúrák telepítését és ültetvények korszerüsítését megelőző alaptrágyázások irányelvei "(Guidelines for basic fertilization prior to planting permanent crops and modernizing plantations), Ed., MÉM NAK 1979, Budapest, pp. 1-47.

Michéli, E.; Fuchs, M.; Láng, V.; Szegi, T.; Dobos, E.; Szabóné, K.G. "Javaslat talajosztályozási rendszerünk m e gú j ít á sá r a : a l a p e l ve k, mó d s z e r e k, alapegységek" (Recommendation for renewing our soil classification system: principles, methods, and basic units). Agrokémia és Talajtan 2015. Akadémia Kiadó, Budapest, pp. 285-297. 
Michéli E. "Talajok képződése és sokfélesége, Magyar Tudomány- A talajok sokfélesége és szerepe a környezetben" (Soil Formation and Diversity, Hungarian Science - Diversity and Role of Soils in the Environment). A Magyar Tudományos Akadémia folyóirata 2016 (The Journal of the Hungarian Academy of Science, in Hungarian), 177, 1156-1161.

MSZ-08-0206-2 (1978). Evaluation of some chemical properties of the soil. Laboratory tests. ( $\mathrm{pH}$ value, phenolphthalein alkalinity expressed in soda, all water-solu ${ }^{-}$ ble salts, hydrolyte and exchanging acidity. Hungarian Standard MSZ-08-0206-2:1978 Section 2.1.

MSZ-08-0205 (1978). Determination of physical and hydro-physical properties of soils. Hungarian Standard MSZ-08-0205:1978, Chapter 5.

MSZ 20135 (1999). Determination of the soluble nutrient element content of the soil. Chapter 4.2.2. 5.1. ALsoluble phosphorus content of soil, Chapter 4.2.1., 5.3. AL-soluble potassium content of soil. pp. 1-12. Hungarian Standard MSZ 20135: 1999.

Pasztor, L.; Korosparti, J.; Bozan, C.; Laborczi, A.; Takacs, K. "Spatial risk assessment of hydrological extremities: Inland excess water hazard, Szabolcs-SzatmarBereg County, Hungary." Journal of Maps 2015, 11(4): 636-644. DOI: 10.1080/17445647.2014.954647

Pető J.; Hüvely A.; Cserni I. "Ültetvénytelepítési programok népszerüsége és tapasztalatai" (Popularity and experience of plantation planting programs), GRADUS 2014, 1(2): 31-36.

Stefanovits, P.; Filep, Gy.; Füleky, Gy. Talajtan (Soil Science), Mezőgazda Kiadó. See:

https://www.tankonyvtar.hu/hu/tartalom/ tamop425/2011_0001_521_Talajtan/ch18.html (Accessed: November 4, 2019)

Sisák, I. "Mai tanulságok a talajosztályozás 1961 és 1999 közötti változásaiból. Vitarovat" (Present lessons from the changes in soil classification between 1961 and 1999. Heading debate). Agrokémia és Talajtan 2016, Akadémia Kiadó, Budapest: 161-168.

Talaj tájékoztató (Soil Information Letter). http:// www.kvvm.hu/szakmai/karmentes/kiadvanyok/talaj_tajekoztato/talaj_tajek-2.htm\#2_2 (KVVM) (Accessed: October 10, 2019.)

Tóth, J. A.; P. T. Nagy; Zs. Krakomperger; Zs. Veres; Zs. Kotroczó; S. Kincses; I. Fekete; M. Papp; K. Lajtha. "Effect of litter fall on soil nutrient content and $\mathrm{pH}$, and its consequences in view of climate change" (Síkfókút DIRT Project). Acta Silvatica et Lignaria Hungarica 2011 7: 75-86.

Tóth J. A., Nagy, P. T., Krakomperger Zs, Veres Zs., Kotroczó Zs., Kincses S., Fekete I., Papp M., Mészáros I. and Viktor O. "The Effects of Climate Change on Element Content and Soil pH" (Síkfőkút DIRT Project, Northern Hungary). In: J. Kozak et al. (eds.), The Carpathians: Integrating Nature and Society Towards Sustainability, Environmental Science and Engineering, Springer-Verlag Berlin Heidelberg 2013 pp. 77-88.

Várallyay, Gy.; Szabóné Kele, G.; Berényi Üveges, J.; Marth, P.; Karkalik, A.; Thury, I. "Magyarország talajainak állapota a Talajvédelmi Információs és Monitoring rendszer (TIM) adatai alapján II. fejezet Magyarország talajai" (The state of Hungarian soils based on Soil Protection Information and Monitoring System (TIM) II. Soils of Hungary). MTA TAKI-NTKSZ 2008, Budapest, pp. 13-28.

WRB - World reference base for soil resources. International soil classification system for naming soils and creating legends for soil maps. World Soil Resources Report No. 106. Chapter 2, pp. 12-21. and Annex 2: Released by Food and Agriculture Organization of the United Nations (FAO), Rome, 2015. On-line: http:// www.fao.org/3/i3794en/I3794en.pdf (Accessed: January 16, 2020.) 